\title{
Deep-sea sediment records of the Laschamp geomagnetic field excursion ( $\sim 41,000$ calendar years before present)
}

\author{
Steve P. Lund and Martha Schwartz \\ Department of Earth Sciences, University of Southern California, Los Angeles, California, USA
}

Lloyd Keigwin

Woods Hole Oceanographic Institution, Woods Hole, Massachusetts, USA

Thomas Johnson

Large Lakes Observatory, University of Minnesota at Duluth, Duluth, Minnesota, USA

Received 16 December 2003; revised 3 August 2004; accepted 26 October 2004; published 2 April 2005.

[1] We have recovered two new high-resolution paleomagnetic records of the Laschamp Excursion ( 41,000 calendar years B.P.) from deep-sea sediments of the western North Atlantic Ocean. The records document that the Laschamp Excursion was characterized locally by (1) declination changes of $\pm 120^{\circ}$, (2) inclination changes of more than $140^{\circ}$, (3) 1200-year oscillations in both inclination and declination, (4) near $90^{\circ}$ out-of-phase relationships between inclinations and declinations that produced two clockwise loops in directions and virtual geomagnetic poles (VGPs) followed by a counterclockwise loop, (5) excursional VGPs during both intervals of clockwise looping, (6) magnetic field intensities less than $10 \%$ of normal that persisted for almost 2000 years, (7) marked similarity in excursional directions over $\sim 5000 \mathrm{~km}$ spatial scale length, and (8) secular variation rates comparable to historic field behavior but persisting in sign for hundreds of years. All of these features, with the exception of anomalously large directional amplitude, are consistent with normal magnetic field secular variation. Comparison of our Laschamp Excursion paleomagnetic records with other late Quaternary excursion records suggests that there is a group of excursions, which we term class I, which have strikingly similar patterns of field behavior and likely share a common cause as part of the overall core dynamo process. Three general models of secular variation are described that can qualitatively produce class I excursions. On the basis of these observations we conclude that class I excursions, epitomized by the Laschamp Excursion, are more closely related to normal secular variation and are not necessarily a prelude to magnetic field reversal.

Citation: Lund, S. P., M. Schwartz, L. Keigwin, and T. Johnson (2005), Deep-sea sediment records of the Laschamp geomagnetic field excursion ( 41,000 calendar years before present), J. Geophys. Res., 110, B04101, doi:10.1029/2003JB002943.

\section{Introduction}

[2] The Earth's magnetic field variability between global polarity reversals, termed secular variation, is the sole direct evidence we have for describing the behavior of the magnetic dynamo that operates in the Earth's outer core and generates the main field. Historic measurements of secular variation have begun to give us realistic constraints on the type of dynamo process that operates in the Earth's outer core [e.g., Gubbins and Bloxham, 1987]. They have also started to provide us with a picture of the outer-core liquid-iron fluid flow patterns that control the style and strength of the dynamo process [e.g., Bloxham and Gubbins, 1985; Bloxham and Jackson, 1992]. How-

Copyright 2005 by the American Geophysical Union. 0148-0227/05/2003JB002943\$09.00 ever, the timescale of historic magnetic field measurements is too short (less than 500 years) to properly characterize the range of temporal scale lengths in the dynamo process [Lund, 1993]. We depend on paleomagnetic secular variation (PSV) studies [Lund, 1989, 1993] to estimate that longer-term field behavior.

[3] PSV studies have noted, on occasion in the prehistoric past, short periods $\left(\sim 10^{3}\right.$ years $)$ of extremely anomalous magnetic field directions, termed excursions, which are unlike anything seen in the historic record. Excursions are simply defined as magnetic field directions whose equivalent virtual geomagnetic poles (VGPs) are between $45^{\circ}$ and $135^{\circ}$ away from the north geographic pole. (VGPs are calculated from local magnetic field directions that locate the magnetic field north pole by assuming the directions are caused by a simple dipole or bar magnet situated at the center of the Earth. VGPs more than $135^{\circ}$ away from 


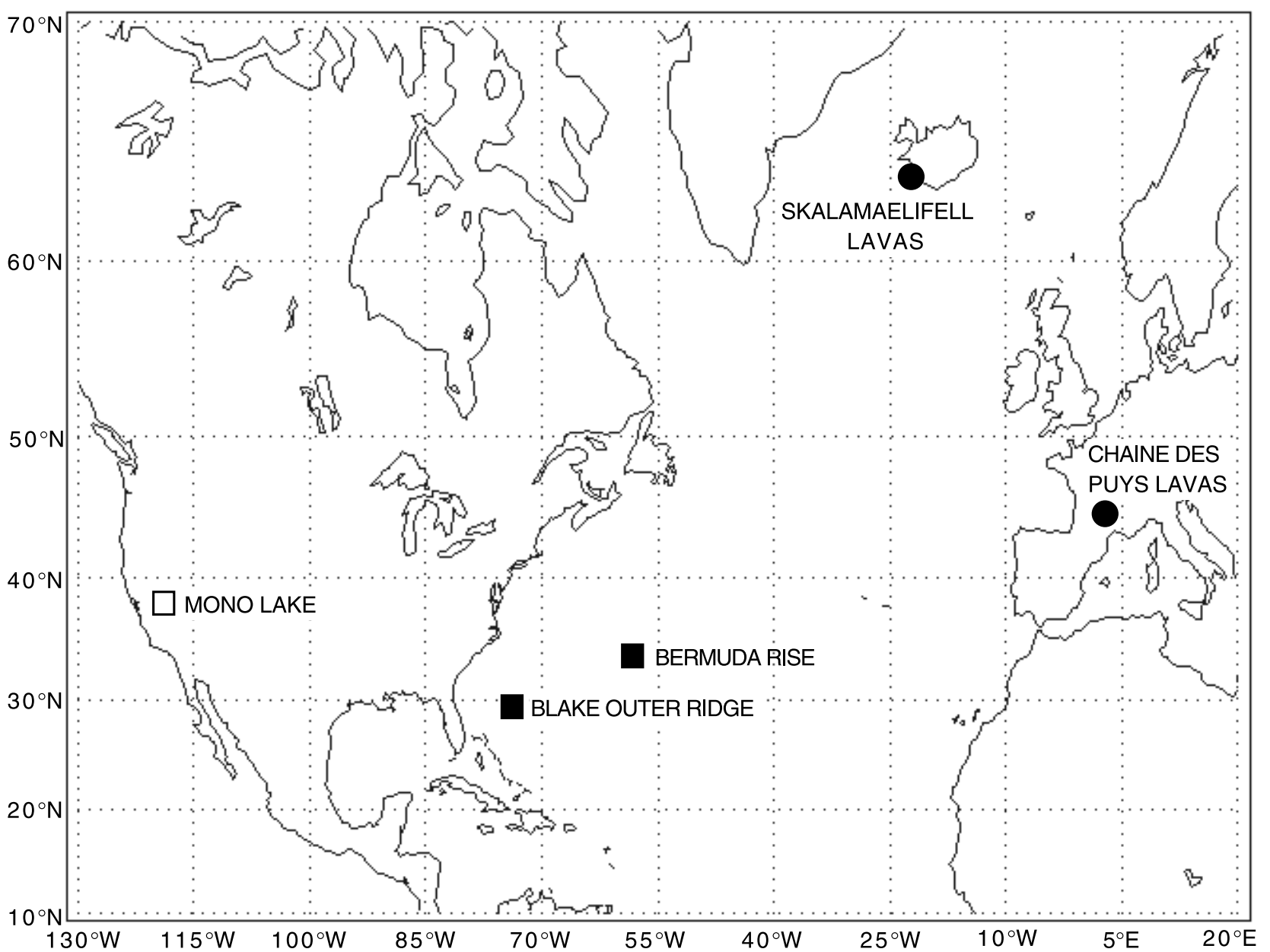

Figure 1. Site map showing the locations of lava flow sequences containing the Laschamp Excursion (Chaine des Puys, France; Skalamaelifell Lavas, Iceland) and deep-sea sediment sequences containing the Laschamp Excursion (submarine Blake Outer Ridge and Bermuda Rise). The site map also indicates the location of Mono Lake, California, where the Mono Lake Excursion was defined.

the north geographic pole and within $45^{\circ}$ of the south geographic pole are usually considered to be reversed in polarity.) The space/time behavior of excursions and their relationship to normal secular variation and polarity reversals are two of the most fundamental unanswered questions in geomagnetism.

[4] We present here replicate paleomagnetic records of the directional and intensity behavior during the Laschamp Excursion ( 41,000 cal years B.P. [Bonhommet and Babkine, 1967]) from hemipelagic sediments of the Blake Outer Ridge and Bermuda Rise, western North Atlantic Ocean, situated about $1500 \mathrm{~km}$ apart. These records provide a complete view of the temporal field variability associated with the Laschamp Excursion. Comparisons of our new paleomagnetic records with the original Laschamp Excursion results from Europe and with paleomagnetic records of the younger $(\sim 31,000$ calendar (cal) years B.P.) Mono Lake excursion [Denham and Cox, 1971; Liddicoat and Coe, 1979] provide an important new perspective for considering the relationship between excursions and both secular variation and field reversals.

\section{Previous Records of the Laschamp Excursion}

[5] The Laschamp Excursion was first observed by Bonhommet and Babkine [1967], based on a paleomagnetic study of Quaternary lava flows from the Chaine des Puys, France (Figure 1). Two different lava flows (Laschamp, Olby) and associated baked contact sediments [Bonhommet, 1972] yielded an anomalous direction with inclination $\mathrm{I}=-66.4^{\circ}$ and declination $\mathrm{D}=237.2^{\circ}$; subsequent paleointensity studies [Roperch et al., 1988] derived a local paleomagnetic field intensity of $7.7 \mu \mathrm{T}$ for this direction. (The average historic field values for this region are about $\mathrm{I}=63^{\circ}, \mathrm{D}=0^{\circ}$, intensity $=50 \mu \mathrm{T}$.) The most recent estimate [Levi et al., 1990] for the age of this anomalous direction is $46,600 \pm 2400$ years B.P. $( \pm 2 \sigma, \mathrm{K} / \mathrm{Ar})$. A related study [Chauvin et al., 1989] of the nearby Louchadiere lava flow has also identified an anomalous 


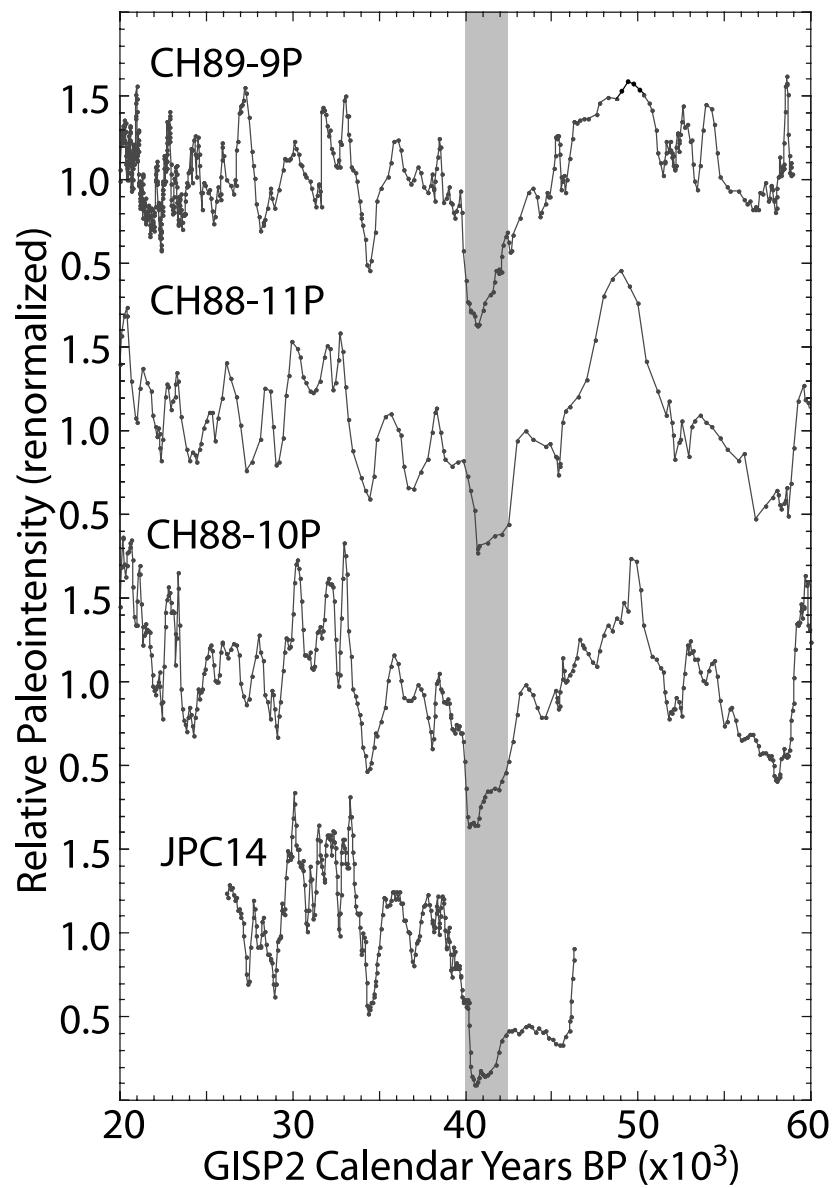

Figure 2. Magnetic field relative paleointensity records from deep-sea sediments of the western North Atlantic Ocean around the time of the Laschamp Excursion. CH899P comes from the Bermuda Rise (Figure 1), while CH8810P, CH88-11P, and JPC14 come from the Blake Outer Ridge (Figure 1). The relative paleointensity records are all determined using the $\mathrm{NRM}_{20} / \mathrm{SIRM}_{20}$ ratio with average values being renormalized to 1.0. The paleointensity low associated with the Laschamp Excursion is indicated by the gray region at $\sim 41,000$ cal years B.P.

paleomagnetic field direction of $\mathrm{I}=58.2^{\circ}$ and $\mathrm{D}=114.1^{\circ}$ with low paleointensity $(12.9 \mu \mathrm{T})$ and an age of $41,700 \pm$ 7,800 years B.P. $( \pm 2 \sigma, \mathrm{K} / \mathrm{Ar})$. Similar paleomagnetic and paleointensity studies [Kristjansson and Gudmundsson, 1980; Levi et al., 1990] of the Skalamaelifell (Icelandic) lava flows (Figure 1) have also identified an anomalous magnetic field direction of $\mathrm{I}=-15.5^{\circ}$ and $\mathrm{D}=258.6^{\circ}$ with very low paleointensity $(4.2 \mu \mathrm{T})$ and an age of $42,900 \pm 7800$ years B.P. $( \pm 2 \sigma, \mathrm{K} / \mathrm{Ar})$. Even though the various lava flows exhibit only three isolated and distinct excursional directions, they are all considered to represent local observations of the same Laschamp Excursion.

[6] The low magnetic field intensities recorded in the Laschamp Excursion lava flows have also been identified in sediment relative paleointensity records from around the world (e.g.; France from Thouveny et al. [1993]; Mediterranean Sea from Tric et al. [1992]; Indian Ocean from Meynadier et al. [1992]; North Atlantic Ocean from Laj et al. [2000], Schwartz et al. [1996, 1998], and Stoner et al.
[2000]; South Atlantic Ocean from Stoner et al. [2002]; and Pacific Ocean from Stott et al. [2002] and Yamazaki and Ioka [1994]). Portions of four sediment paleointensity records from our study area, the western North Atlantic Ocean [Schwartz et al., 1996, 1998], are shown in Figure 2 as examples. These records all provide a reproducible estimate of magnetic field intensity in the western North Atlantic region for most of the last 100,000 years, and they all contain a significant low in intensity around $\sim 40,000-$ 42,000 cal years B.P. However, most of the published sediment paleomagnetic records from around the world do not contain excursional directions associated with the paleointensity low. This could be due to low sedimentation rates $(<10 \mathrm{~cm} / \mathrm{kyr})$ at these sites during the excursion time interval and a significant degree of smearing of the sediment natural remanent magnetization (NRM).

[7] The western North Atlantic (Blake Outer Ridge) paleointensity record [Schwartz et al., 1996, 1998] and associated directional record [Lund, 1993; Lund et al., 2001] from piston core $\mathrm{CH} 88-10 \mathrm{P}\left(29.6^{\circ} \mathrm{N}, 286.7^{\circ} \mathrm{E}\right)$ illustrate this problem. Core CH88-10P contains a distinctive interval of low paleointensity at $40,000-42,000 \mathrm{cal}$ years B.P. (Figures 2 and 3), which we associate with the

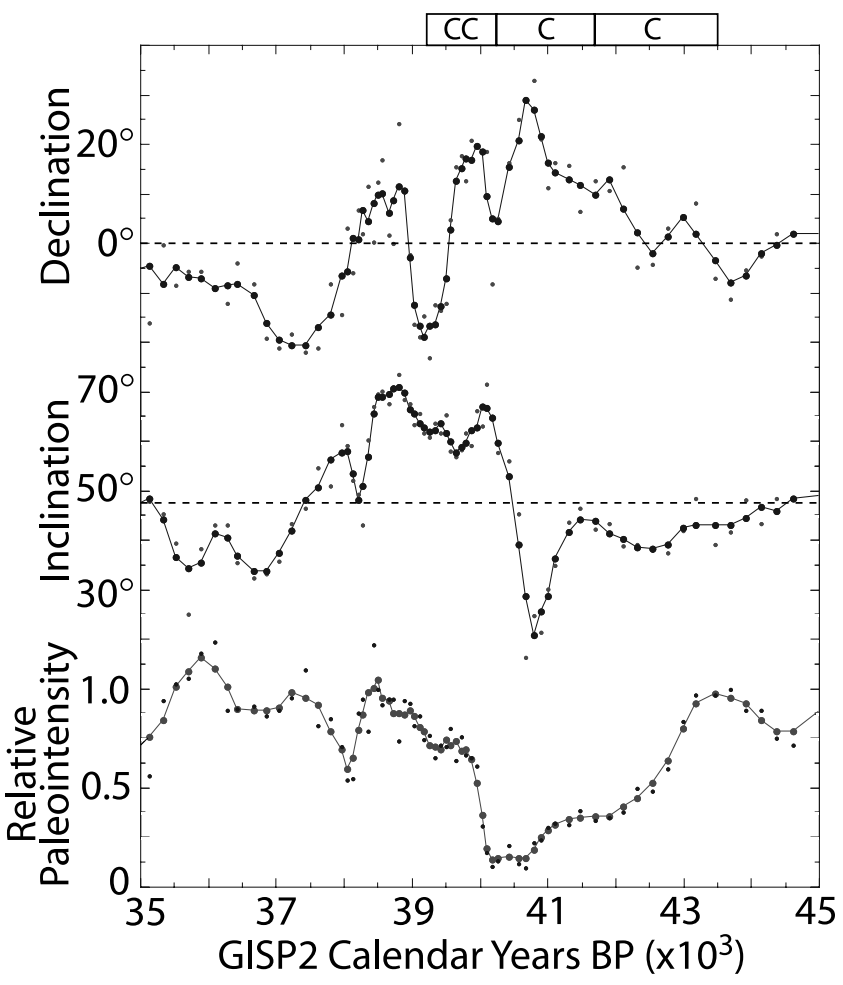

Figure 3. Paleomagnetic secular variation and relative paleointensity records (see also Figure 2) from Blake Outer Ridge core CH88-10P around the time of the Laschamp Excursion. These records show a distinctive interval of low paleointensity associated with a large, but not excursional, swing in inclination between $\sim 39,000$ and 42,000 cal years B.P. that we consider to be a smeared record of the Laschamp Excursion. Almost identical records have also been recovered from nearby (within $100 \mathrm{~km}$ ) cores CH88-11P and CH89-1P. Boxes at top indicate intervals of clockwise (C) or counterclockwise (CC) looping (circularity) in the directional data. 


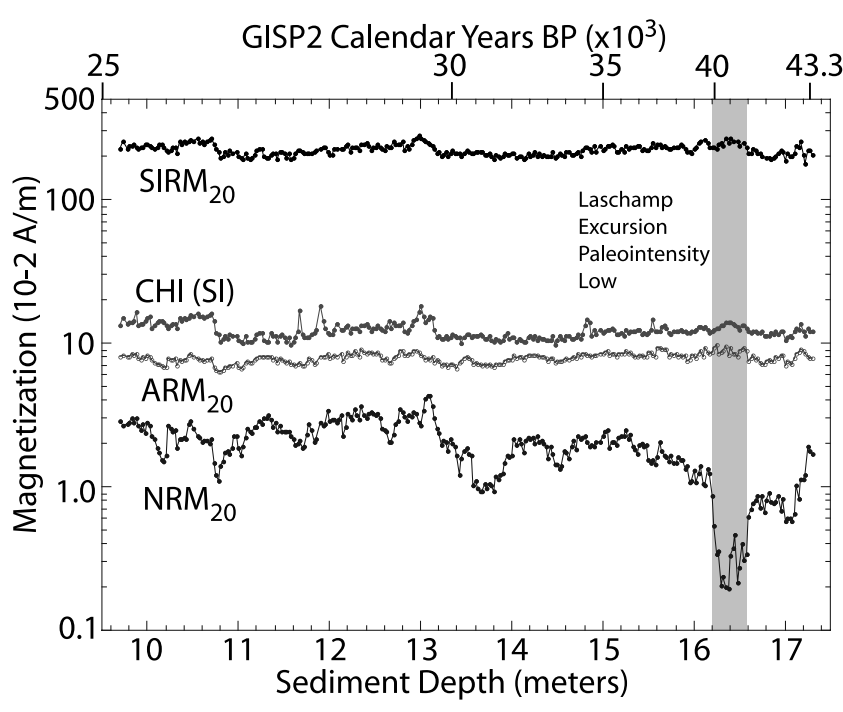

Figure 4. Sediment magnetism for core JPC14. The natural remanence (NRM), anhysteretic remanence $(\mathrm{ARM})$, saturation isothermal remanence (SIRM) (all demagnetized at $20 \mathrm{mT} \mathrm{AF}$ ), and magnetic susceptibility (CHI) are plotted versus both depth and time. The interval of the Laschamp Excursion and associated paleointensity low is noted in gray. Note that the sediment magnetic parameters $\mathrm{CHI}, \mathrm{ARM}_{20}$, and $\mathrm{SIRM}_{20}$ vary by less than a factor of 2 .

Laschamp Excursion low paleointensities in Europe, and a distinctive shift in inclination from $15^{\circ}$ to $70^{\circ}$ that is associated with easterly declinations (Figure 3 ). The $55^{\circ}$ change in inclination is exceptional by the standards of normal PSV, but the directional variability is not anomalous enough to be termed excursional (VGPs are less than $45^{\circ}$ away from the north geographic pole). The $\delta^{18} \mathrm{O}$ and carbonate stratigraphy [Haskell, 1991; Haskell et al., 1991] indicate that the sedimentation rate in this core is $19 \mathrm{~cm} / \mathrm{kyr}$ during oxygen isotope stage $3(24,000-59,000$ cal years B.P.). However, AMS radiocarbon dating of high-frequency carbonate oscillations [Keigwin and Jones, 1994] which occur in this core and correlations to the GISP2 ice core chronology [Lund et al., 2001] suggest that the sedimentation rate right around the time of the Laschamp Excursion is closer to $15 \mathrm{~cm} / \mathrm{kyr}$. The GISP2 (calendar year) chronology for CH88-10P [Lund et al., 2001] places the low intensity interval we associate with the Laschamp Excursion at $40,000-42,000$ cal years B.P., which is consistent with the $\mathrm{K} / \mathrm{Ar}$ age estimates for the European Laschamp lava flows. We previously suggested [Lund et al., 1989], on the basis of this record, that the Laschamp Excursion is regional in nature (centered in western Europe) and that CH88-10P displays a "far-field", nonexcursional, view of that excursion. However, the best estimate of sedimentation rate in this interval, $15 \mathrm{~cm} / \mathrm{kyr}$, may be low enough that significant smearing of the sediment NRM might have occurred [Lund and Keigwin, 1994], thus masking any true excursional directions in this record.

[8] A number of other sediment paleomagnetic records from around the world do have anomalous directions around 41,000 cal years B.P. that are associated with the
Laschamp Excursion (e.g., South Atlantic Ocean from Channell et al. [2000]; Gulf of California from Levi and Karlin [1989]; Japan from Hirooka et al. [1977]; Russia from Kulikova and Pospelova [1979]; and North Atlantic Ocean (inclination only) from Kissel et al. [1999]). However, none of these records display sufficient detail to characterize the overall pattern of anomalous directional variability associated with the excursion or its relationship to surrounding secular variation. Also, most of these records have not been replicated locally to confirm their observed anomalous directions. As such, these records can be viewed as corroborating the existence of the Laschamp Excursion but not its detailed space/time pattern of directional variability.

[9] It is important to note separately the existence of a distinctive set of deep-sea sediment paleomagnetic records from the high-latitude Arctic Ocean [Bleil and Gard, 1989; Nowaczyk and Baumann, 1992; Nowaczyk et al., 1994; Nowaczyk and Antonov, 1997; Nowaczyk and Knies, 2000] that reproducibly record an excursion about 41,000 cal years B.P., which the records consider to be the Laschamp Excursion. However, the pattern of excursional field behavior in these Arctic Ocean records is significantly different from the results we present herein. The Arctic records document a full polarity reversal that remains stable for several thousand years, while we observe a cyclically evolving pattern of anomalous directional variability. We will discuss the implications of these differences below.

\section{New Directional and Paleointensity Records of the Laschamp Excursion}

[10] We have recently studied two more deep-sea sediment cores from the Blake Outer Ridge (KNORR 140/2$\left.\mathrm{JPC} 14,28.6^{\circ} \mathrm{N}, 286.9^{\circ} \mathrm{E}\right)$ and the Bermuda Rise (CH89-9P,

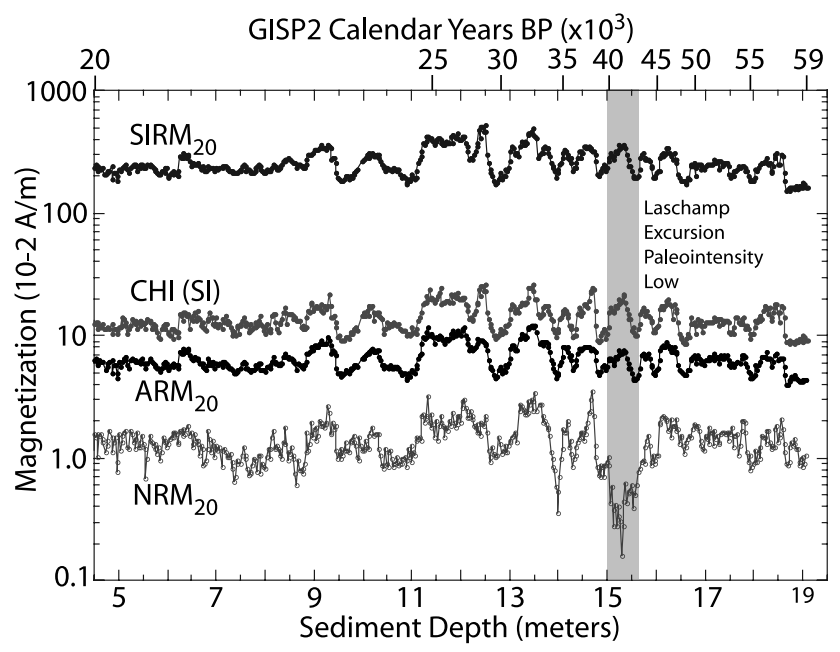

Figure 5. Sediment magnetism for core CH89-9P. NRM, ARM, SIRM (all demagnetized at $20 \mathrm{mT} \mathrm{AF}$ ), and CHI are plotted versus both depth and time. The interval of the Laschamp Excursion and associated paleointensity low is noted in gray. Note that the sediment magnetic parameters CHI, $\mathrm{ARM}_{20}$, and $\mathrm{SIRM}_{20}$ vary by less than a factor of 3 . 

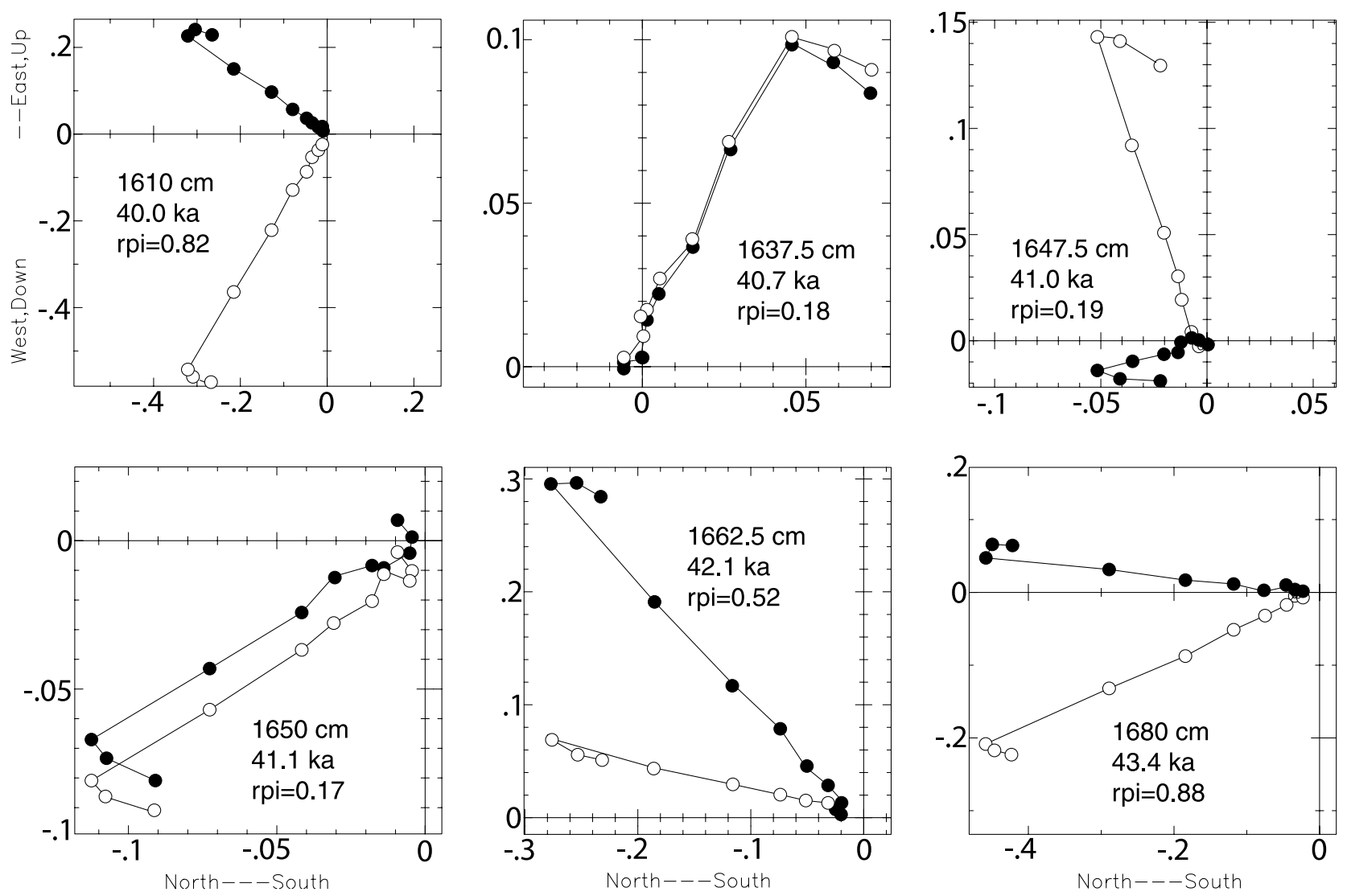

Figure 6. Alternating field demagnetization plots for selected sediment horizons through the Laschamp Excursion in deep-sea sediment core JPC14. The horizontal components (solid dots) and vertical components (open dots) of the NRM are plotted starting with initial NRM and continue at $10 \mathrm{mT}$ demagnetization steps up to $100 \mathrm{mT}$. It is clear, in all cases, that a well-defined characteristic remanence is removed between 20 and $80 \mathrm{mT}$; "rpi" stands for relative paleointensity values. Ages for each horizon are also noted $(\mathrm{ka})$.

$33.7^{\circ} \mathrm{N}, 302.4^{\circ} \mathrm{E}$; Figure 1), which have significantly higher sediment accumulation rates. On the basis of sediment magnetic correlations between JPC14 and CH88-10P, we have determined that the average sedimentation rate in JPC14 during oxygen isotope stage 3 is $35 \mathrm{~cm} / \mathrm{kyr}$ and the average sedimentation rate around the time of the Laschamp Excursion is about $28 \mathrm{~cm} / \mathrm{kyr}$. On the basis of carbonate stratigraphy [Keigwin and Jones, 1994] and sediment magnetic correlations with $\mathrm{CH} 88$-10P, we have determined that the average sedimentation rate in CH89-9P during oxygen isotope stage 3 is $22 \mathrm{~cm} / \mathrm{kyr}$ and the average sedimentation rate around the time of the Laschamp Excursion is about $20 \mathrm{~cm} / \mathrm{kyr}$. These rates are significantly higher (almost a factor of 2 for JPC14) than was noted in core CH88-10P.

[11] We have carried out detailed paleomagnetic and sediment magnetic studies on the sediment intervals surrounding the Laschamp Excursion within both cores. Single $2-\mathrm{cm}$ sediment cubes were taken every $2.5 \mathrm{~cm}$ and treated in the following manner. Sample natural remanent magnetizations (NRMs) and magnetic susceptibility were initially measured, and then the NRMs of samples within $50 \mathrm{~cm}$ of the excursion interval were stepwise alternating magnetic field (AF) demagnetized every $10 \mathrm{mT}$ up to $100 \mathrm{mT}$. Sample NRMs outside this interval were AF demagnetized at $20 \mathrm{mT}$ and $60 \mathrm{mT}$. All samples were then given an anhysteretic remanence (ARM) and AF demagnetized at the same steps as the NRM. Finally, every sample was given an saturation isothermal remanence (SIRM, 1.25 T) followed by IRMs at -0.1 and $-0.3 \mathrm{~T}$ [King and Channell, 1991]. The sediment magnetic measurements are summarized in Figures 4 and 5.

[12] In all cases, the sample NRMs contained a distinctive characteristic remanence, which was demagnetized between 20 and $80 \mathrm{mT}$ and almost always demagnetized straight toward the origin. Within the excursion intervals we used the characteristic remanence as our cleaned NRM directions; outside the excursion intervals, we used the $20 \mathrm{mT}$ demagnetized NRMs as our cleaned NRM directions. Typical AF demagnetization curves through the excursional intervals are displayed in Figures 6 (JPC14) and 7 (CH89-9P). We see almost no evidence for significant NRM smearing in sequential comparison of our characteristic remanences; we do note consistently that NRMs with good characteristic remanences and excursional directions are present during times of apparently very low magnetic field intensity.

[13] Figure 8 displays cleaned inclination and declination records for cores CH88-10P, CH89-9P, and JPC14 in the time interval $10-45,000{ }^{14} \mathrm{C}$ years B.P. [from Lund et al., 2001]. All PSV records are rotated to zero degrees average 

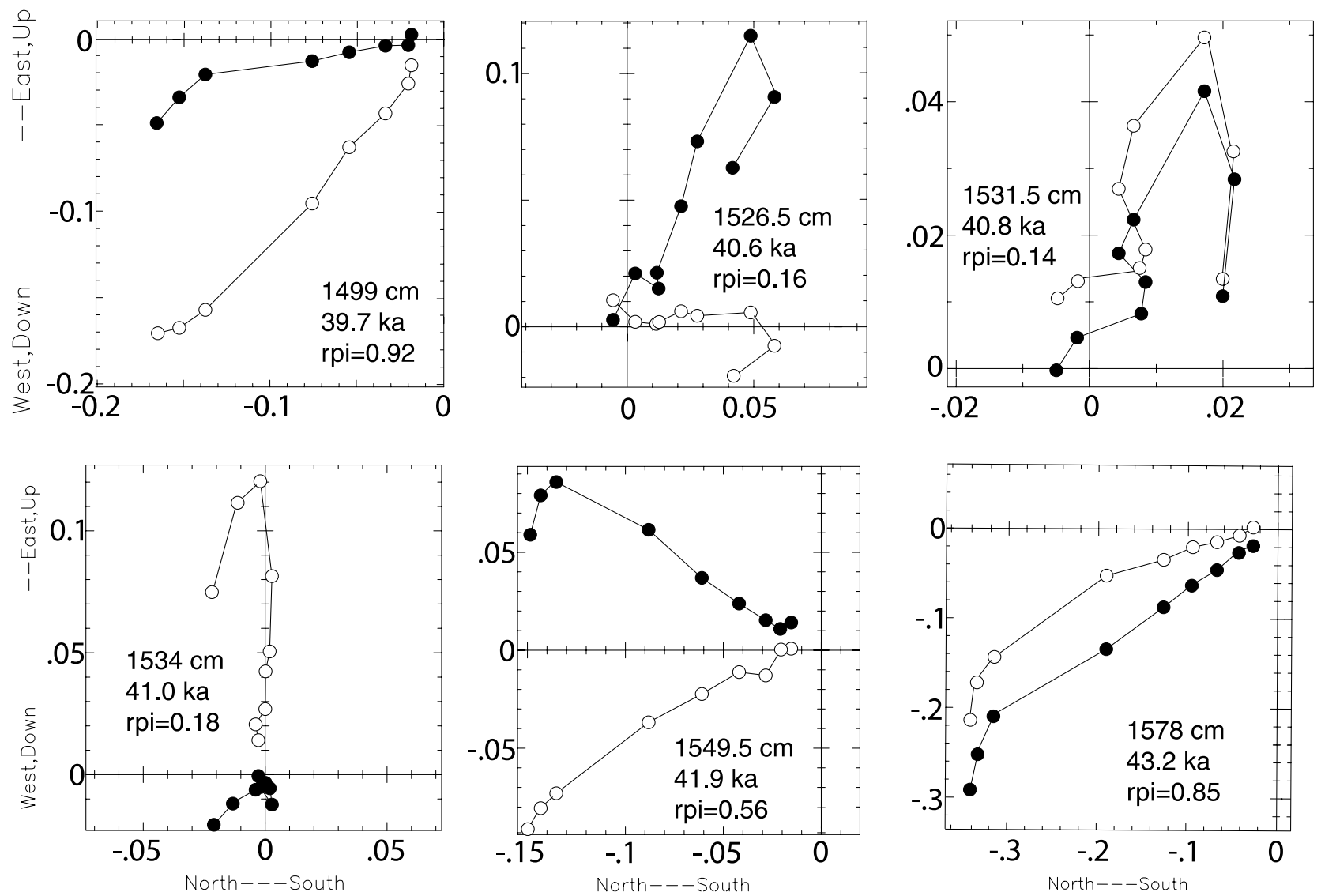

Figure 7. Alternating field demagnetization plots for selected sediment horizons through the Laschamp Excursion in deep-sea sediment core CH89-9P. The horizontal components (solid dots) and vertical components (open dots) of the NRM are plotted starting with initial NRM and continue at $10 \mathrm{mT}$ demagnetization steps up to $80 \mathrm{mT}$. It is clear, in all cases, that a well-defined characteristic remanence is removed between 20 and $80 \mathrm{mT}$; "rpi" stands for relative paleointensity values. Ages for each horizon are also noted $(\mathrm{ka})$.

declination. The declination offsets at core segment boundaries in each core have been corrected by matching regional overlaps with declination data from other cores in Figure 8 as was done by Lund and Banerjee [1985]. The excursion records in JPC14 and CH89-9P both occur in single core segments. Selected inclination and declination features are indicated to show the quality of the correlation between cores separated by as much as $1500 \mathrm{~km}$ from one another. Features I22-24 and D23-26 represent the interval of the Laschamp Excursion.

[14] The NRM, ARM, and SIRM intensity variability and overall patterns of NRM, ARM, and SIRM demagnetization in cores JPC14 (Figure 4) [Schwartz, 1997] and CH89-9P (Figure 5) are almost identical to results from cores CH88-10P and CH88-11P, previously published by Schwartz et al. [1996, 1998]. On that basis, we have used the ratio $\mathrm{NRM}_{20} / \mathrm{SIRM}_{20}$ as the best indicator of relative paleointensity within both cores. The final paleointensity records for JPC14 and CH89-9P (Figure 2) are almost identical to the previously published paleointensity records from CH88-10P and CH88-11P (Figure 2). (All sediment and paleomagnetic magnetic data for cores CH88-10P, CH88-11P, CH89-9P, and JPC14 are available as Excel files at http://earth.usc.edu/ slund.)
[15] The Laschamp relative paleointensity and cleaned directional variations recorded in these two cores are shown in Figures 9 and 10. The relative paleointensity results in both cores are almost identical to that seen in CH88-10P (Figures 2 and 3), but the directions are quite different. The declinations display almost a full reversal $\left(\sim \pm 120^{\circ}\right.$ change in direction) while the inclinations go through more than a full reversal (from site axial dipole inclination of $49^{\circ}$ to $-49^{\circ}$ ) reaching inclinations near $-80^{\circ}$ ! The $\mathrm{CH} 88-10 \mathrm{P}$ record only reaches $15^{\circ}$ inclination in this interval. High inclination values occur after the excursion in all of the records and there is a tendency for easterly declinations in all records but the $\mathrm{CH} 88-10 \mathrm{P}$ record is too smeared to record the details of the large-amplitude declination swings in JPC14 and CH89-9P.

[16] Although the three excursional directions associated with the Laschamp Excursion in European lavas do not have age assignments good enough to correlate with specific horizons in the deep sea sediment cores, their overall ages are not significantly different from the interval of anomalous directional and paleointensity variability noted Figures 9 and 10 . We can test their correlation more quantitatively, however, by estimating what the three European excursional directions should be at the site of 
A

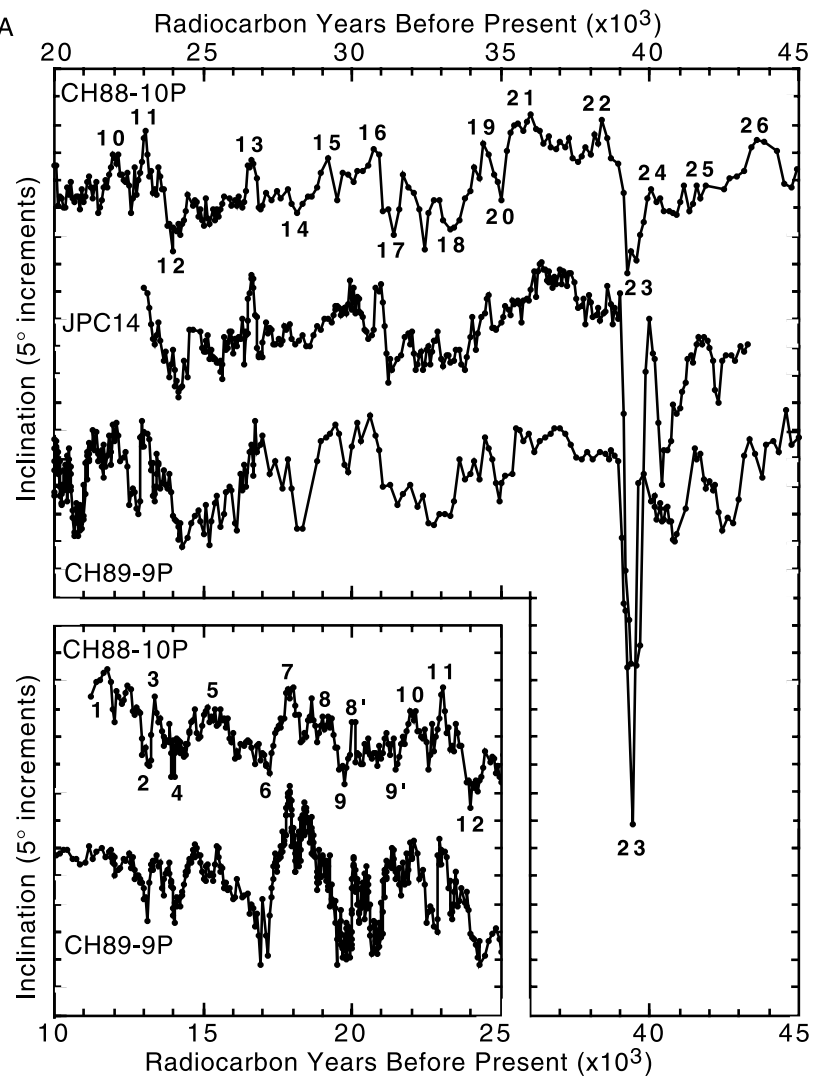

B

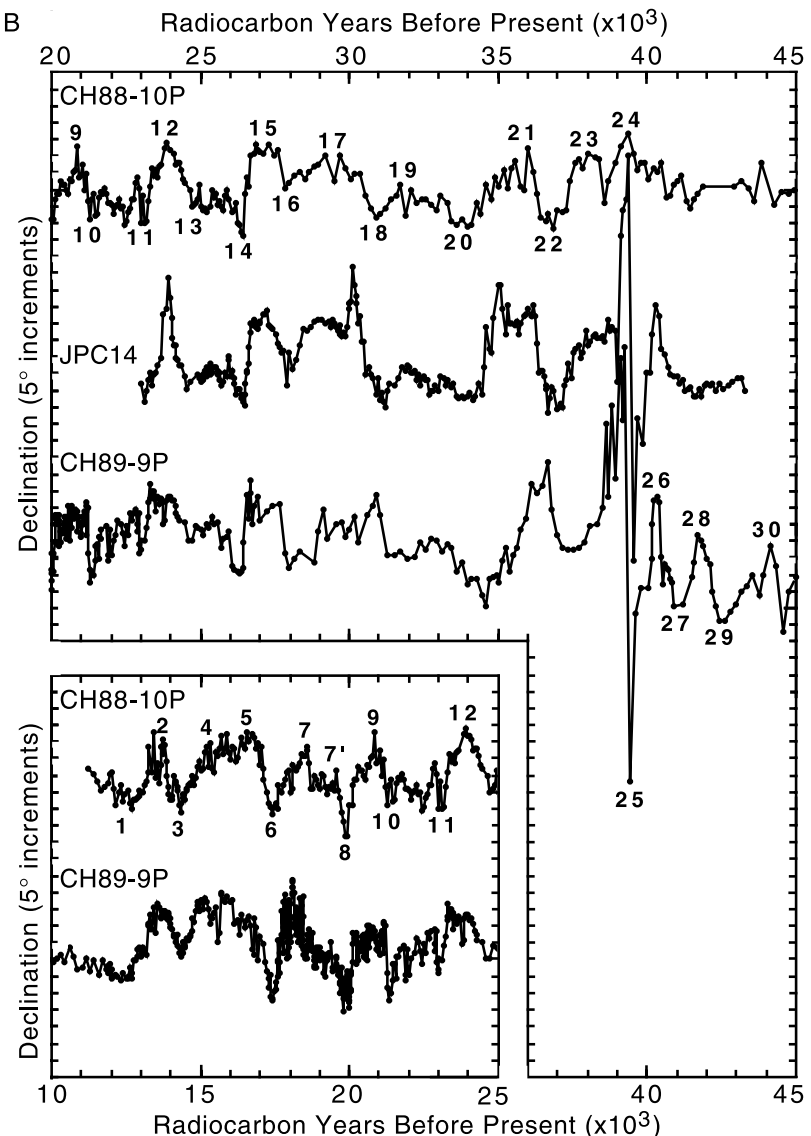

Figure 8. (a) Cleaned $(20 \mathrm{mT})$ paleomagnetic field inclination records for cores CH88-10P, CH89-9P, and JPC14. (b) Cleaned ( $20 \mathrm{mT}$ ) paleomagnetic field declination records for cores CH88-10P, CH89-9P, and JPC14. Selected PSV features, which can be correlated between the sites, are numbered for clarity. See text for further discussion. From Lund et al. [2001].

JPC14 or CH89-9P, based on a dipole mapping (the simplest and generally most accepted mapping, and one that may be appropriate for short-distance regional correlations even under these circumstances). The three mapped directions are shown in Figures 9 and 10 (open diamonds) and placed at stratigraphic horizons, which have the closest correspondence to observed data from JPC14 or CH89-9P. It is clear, in all three cases, that directions from selected horizons within the JPC14 and CH89-9P records of the Laschamp Excursion can be found, which are not significantly different from the three European directions (after dipole mapping). Moreover, these three horizons all occur in the interval of lowest observed paleointensity in both sediment PSV records. The similarity of these directions and paleointensities suggests that our two new deepsea sediment records do accurately record the local pattern of field behavior at the time of the Laschamp Excursion. Also, on the basis of these strong correlations, we would argue that all of these data record aspects of the same Laschamp Excursion and share the same causative dynamo source mechanism on a regional scale.

[17] The paleomagnetic results from cores JPC14 and CH89-9P have also been corroborated by shipboard and $u$ channel measurements of deep-sea sediments from Ocean Drilling Program Leg 172 Sites 1061 (Blake/Bahama Outer Ridge) and 1063 (Bermuda Rise) [Lund et al., 2001]. All of the PSV features in Figure 8 are present in the Leg 172 sediments and the $u$ channel data for Sites 1061 and 1063 [Lund et al., 2001] display all of the excursion features noted in Figures 9 and 10. The problem with $u$ channel measurements of the excursion is the potential for signal aliasing due to significant directional changes within the region of sample measurement $(\sim 10 \mathrm{~cm})$. Also, JPC14 is from another region on the Blake/Bahama Outer Ridge that had significantly higher sediment accumulation rates relative to Site 1061. Both of these reasons indicate that the JPC14 and CH89-9P paleomagnetic records of the Laschamp Excursion shown in Figures 9 and 10 represent the best evidence available for its pattern of variability.

\section{Characteristics of the Laschamp Excursion in the Western North Atlantic Region}

[18] The Laschamp Excursional field behavior recorded in both JPC14 and CH89-9P displays a distinctive oscillatory behavior in both inclination and declination, which grows in amplitude as the field makes a noticeable step decrease in intensity and then diminishes again as the field makes a step increase in intensity. Assuming a sedimentation rate of $28 \mathrm{~cm} / \mathrm{kyr}$ for JPC14, these oscillations have a period of about 1200 years. The interval of lowest intensity is less than 2000 years in duration. During the interval of 


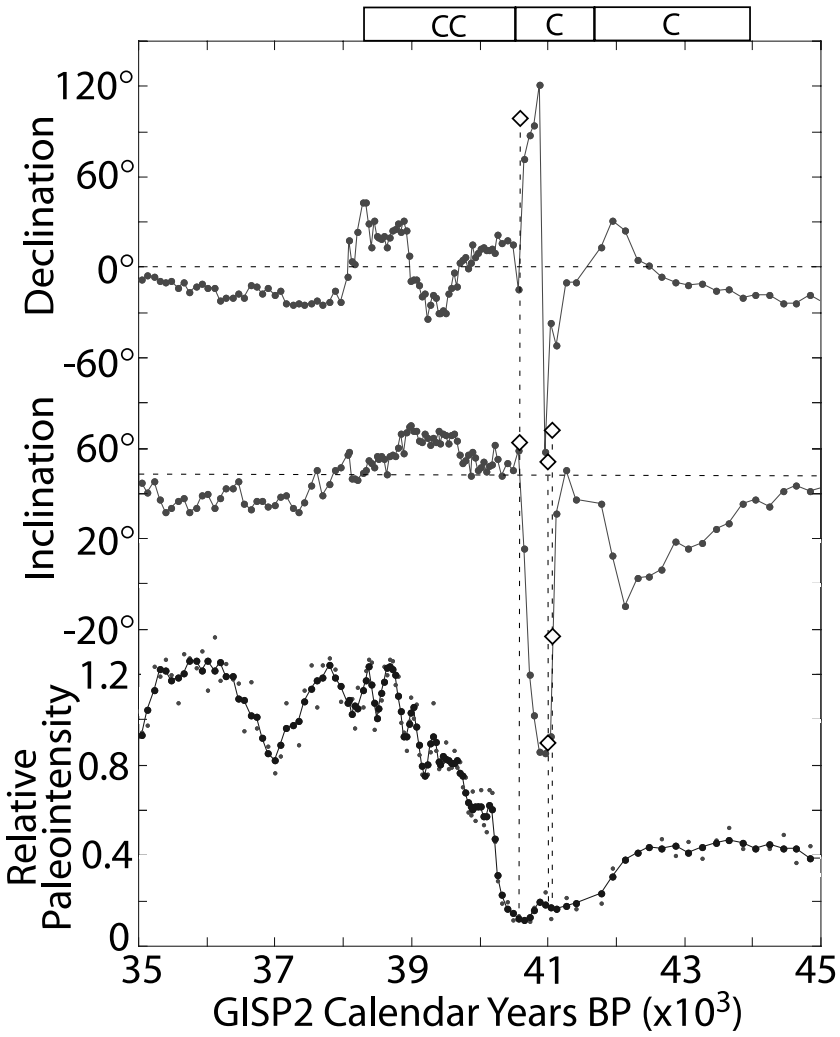

Figure 9. Paleomagnetic secular variation and relative paleointensity (small dots are original data, large dots are 3-point running average) records from Blake Outer Ridge core JPC14 for the time interval of the Laschamp Excursion. NRM after $20 \mathrm{mT}$ demagnetization was used outside the excursion interval, and NRM characteristic remanences were used in the excursion interval. These records show the same distinctive interval of low paleointensity seen in other cores (Figures 2 and 3). However, it contains a much more dramatic pattern of directional variability that we consider to be a more accurate and high-resolution record of the Laschamp Excursion as seen on the Blake Outer Ridge. The dashed lines indicate three time intervals where directions in this record are almost identical to the Laschamp Excursion directions seen in Europe (open diamonds). These three intervals also have similar paleointensity lows. Boxes at top indicate intervals of clockwise (C) or counterclockwise (CC) looping (circularity) in the directional data.

low paleointensity, the inclination dips first to $-10^{\circ}$ (in JPC14; only $20^{\circ}$ in CH89-9P) and then to $-80^{\circ}$ (almost becoming a dip pole) while the declination undergoes a $\sim \pm 120^{\circ}$ reversal in direction before returning to normal values.

[19] These inclination and declination oscillations produce two complete clockwise loops in the overall field vector directions (note intervals with $\mathrm{C}$ at the top of Figures 9 and 10) and VGPs (Figure 11), each with a duration of about 1200 years. The open loops are a manifestation of the near $90^{\circ}$ out-of-phase relationship between the inclination and declination oscillations. The older clockwise VGP loop reaches $35^{\circ} \mathrm{N}$ latitude in JPC14 and is therefore excursional, while the older VGP loop in
CH89-9P only reaches $50^{\circ} \mathrm{N}$ latitude (Figure 11). Both cores reach excursional VGP latitudes near $45^{\circ} \mathrm{S}$ latitude in the younger clockwise loop. At our core sites, we consider the Laschamp Excursion to be a complex vector waveform [Lund, 1993, 1996] involving both clockwise loops. Core CH88-10P also shows the same two clockwise loops (Figures 3 and 12), but they are smaller in amplitude because of more significant smearing of that paleomagnetic record. All three cores also contain a third counterclockwise loop after the Laschamp Excursion (intervals labeled CC in Figures 3, 9, and 10).

[20] If we scale the relative paleointensity values in Figures 9 and 10 to values appropriate to the Earth's geomagnetic field [e.g., Tric et al., 1992] and use the

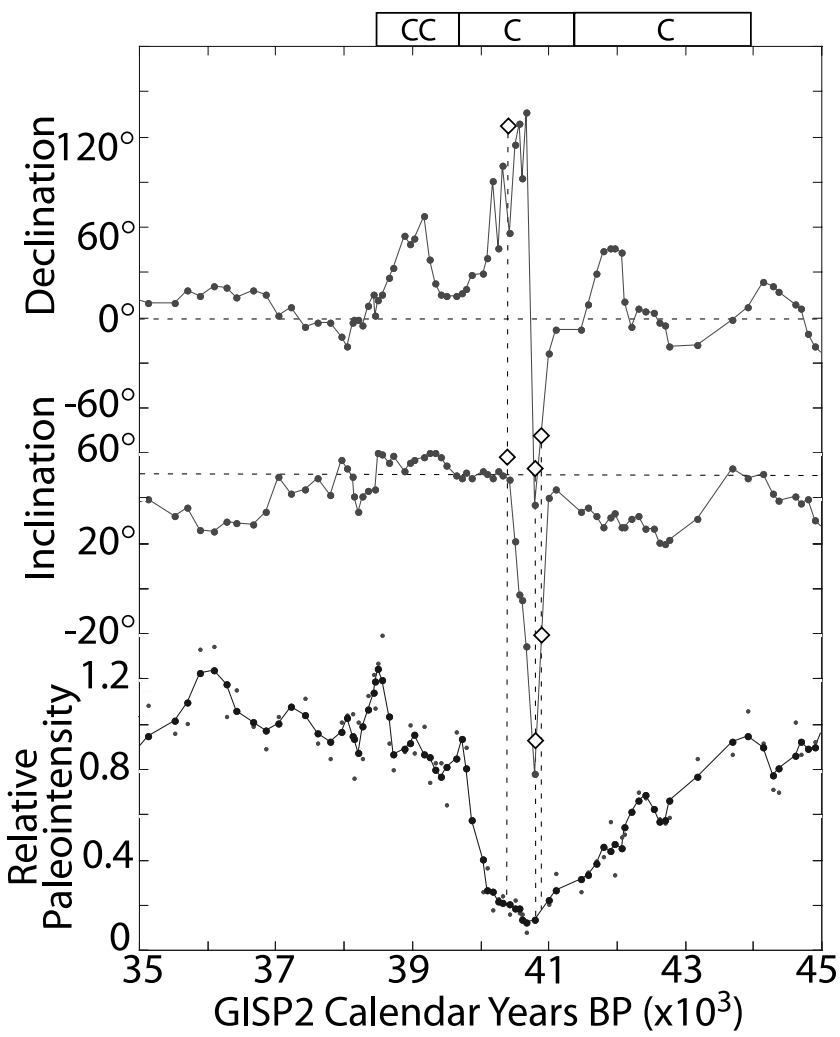

Figure 10. Paleomagnetic secular variation and relative paleointensity (small dots are original data, large dots are 3-point running average) records from Bermuda Rise core CH89-9P for the time interval of the Laschamp Excursion. NRM after $20 \mathrm{mT}$ demagnetization was used outside the excursion interval, and NRM characteristic remanences were used in the excursion interval. This record also shows the same distinctive interval of low paleointensity seen in other cores (Figures 2, 3, and 9). Also, it contains a dramatic pattern of directional variability, which we associate with the Laschamp Excursion. The pattern of directional variability is extremely similar to that seen on the Blake Outer Ridge (Figure 9). Like the JPC14 record, there are three time intervals in this record where directions and paleointensities are almost identical to the Laschamp Excursion directions seen in Europe (open diamonds). Boxes at top indicate intervals of clockwise (C) or counterclockwise (CC) looping (circularity) in the directional data. 

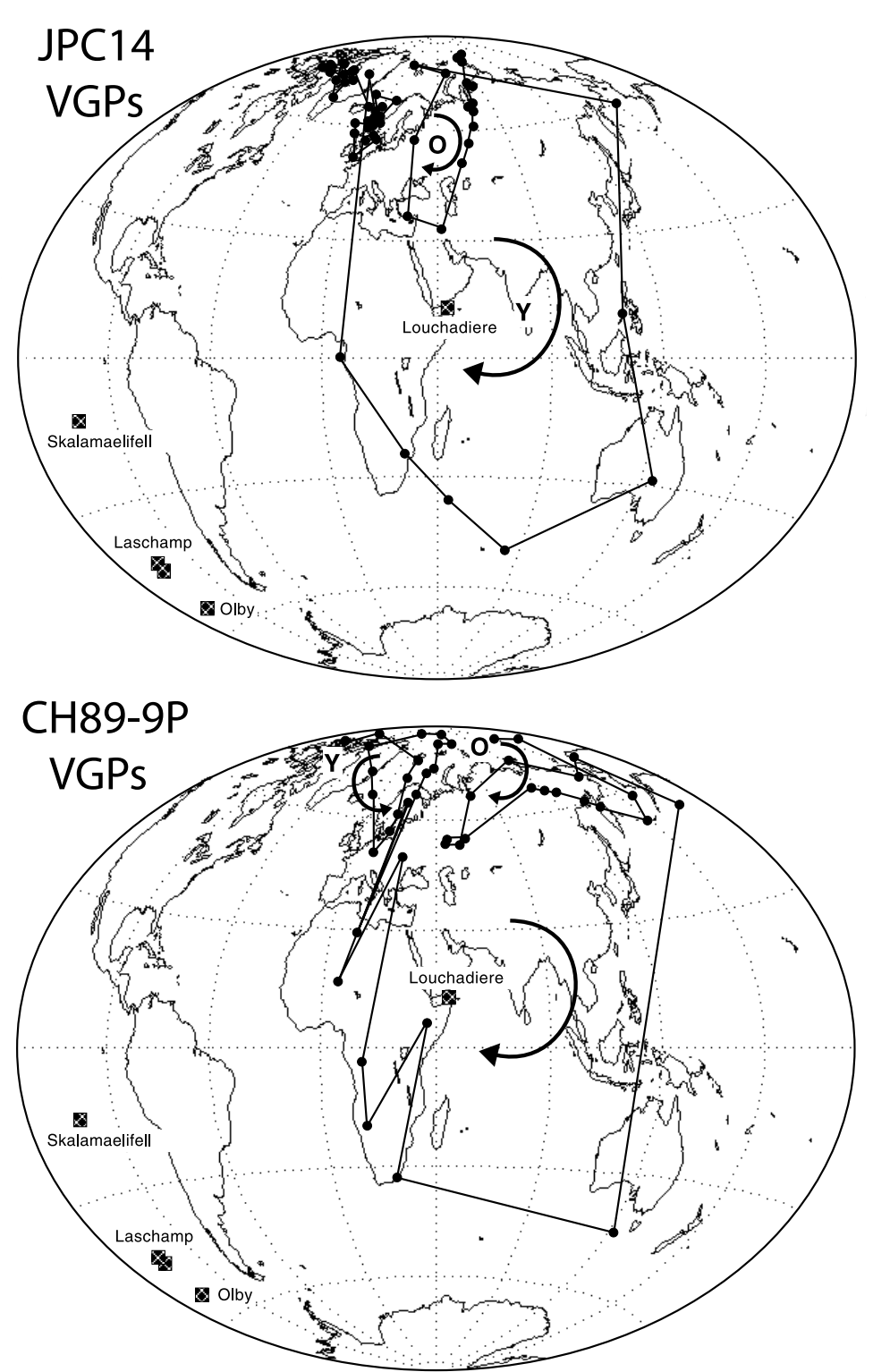

Figure 11. Virtual geomagnetic pole (VGP) paths associated with the Laschamp Excursion records from JPC14 and CH89-9P. Both records show a very distinctive pattern of two successive clockwise loops in the VGP paths, the first smaller (yet truly excursional in the JPC14 record reaching paleolatitudes of $34^{\circ} \mathrm{N}$ ) and the second much larger in amplitude. $\mathrm{O}$ is the oldest loop, and $\mathrm{Y}$ is the youngest loop in each record; the arrows indicate direction of looping. The individual VGPs of the European Laschamp Excursion lavas are shown for comparison.

sedimentation rates described above, we can also calculate the time-averaged rates of secular variation associated with the Laschamp Excursion. The relative paleointensity values in CH89-9P were multiplied by 1.25 to scale them to the values of JPC14 and all paleointensities were assigned values of gauss $\left(=10^{5} \mathrm{nT}\right)$. On this basis, paleointensities after the Laschamp Excursion averaged $0.3 \mathrm{G}$ or $30,000 \mathrm{nT}$, values not unreasonable based on previous studies [e.g., Tric et al., 1992]. Secular variation rates were then calculated for total directional changes $(\mathrm{dV} / \mathrm{dt}$; arc $\mathrm{min} / \mathrm{yr}$ ) and total intensity changes $(\mathrm{dJ} / \mathrm{dt} ; \mathrm{nT} / \mathrm{yr})$ and plotted in Figure 13.
[21] The rates of intensity change are typically less than $50 \mathrm{nT} / \mathrm{yr}$ and never more than $150 \mathrm{nT} / \mathrm{yr}$. These values are not significantly different from historic field intensity rates [Peddie and Zunde, 1988] except that historic values are true rates per year while the paleomagnetic results are rates averaged over 90 (JPC14) to 125 (CH89-9P) years. The rates of paleomagnetic directional changes are typically less than $30 \mathrm{arc} \mathrm{min} / \mathrm{yr}$ and never more than $70 \mathrm{arc} \mathrm{min} / \mathrm{yr}$, while the highest historic rates are less than $40 \mathrm{arc} \mathrm{min} / \mathrm{yr}$ [Peddie and Zunde, 1988]. All in all, the paleomagnetic rates of secular variation around the time of the Laschamp Excur- 

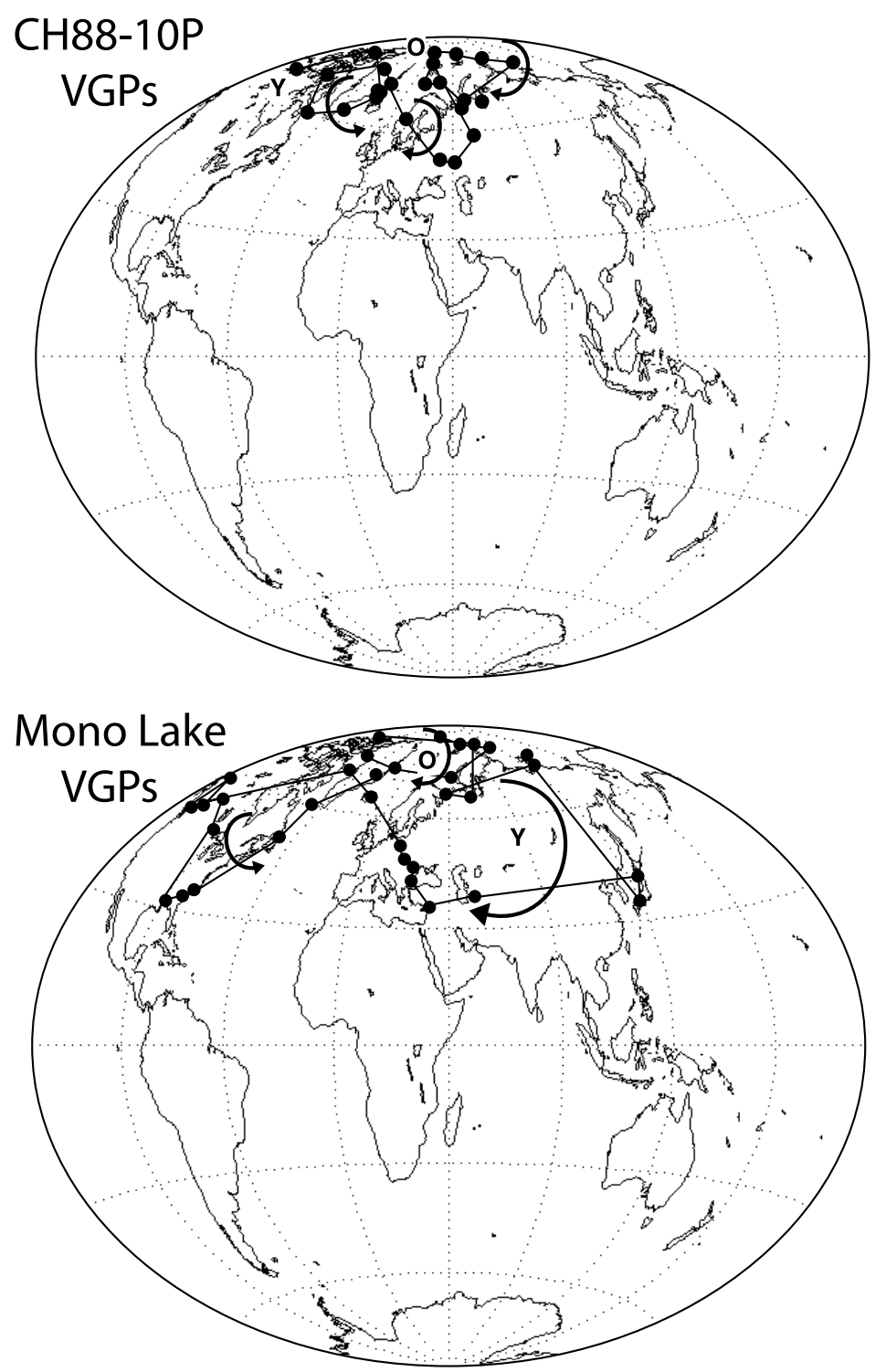

Figure 12. Virtual geomagnetic pole (VGP) paths associated with the Laschamp Excursion record from CH88-10P and the Mono Lake Excursion record from Mono Lake, California. The CH88-10P Laschamp Excursion VGP path is similar in style to those in Figure 11, but the VGP loops are smaller in size due presumably to sediment smearing of the CH88-10P paleomagnetic record. The Mono Lake Excursion VGP path shows a very similar pattern of VGP looping to that noted for the Laschamp Excursion (Figure 11), but here the truly excursional directions occur in the younger clockwise loop and subsequent counterclockwise loop. $\mathrm{O}$ is the oldest loop, and $\mathrm{Y}$ is the youngest loop in each record; the arrows indicate direction of looping.

sion are not particularly anomalous, they just persist in sign for hundreds of years.

[22] The most distinctive features of the secular variation rates are perhaps (1) the persistence of moderate to high rates of directional change for almost 1000 years within the youngest clockwise loop (gray intervals, Figure 13), which is the main part of the Laschamp Excursion, and (2) the suggestion that high rates of directional and intensity changes are $90^{\circ}$ out of phase. This is illustrated in Figure 14 where $\mathrm{dV} / \mathrm{dt}$ is plotted against $\mathrm{dJ} / \mathrm{dt}$ for both records. It is clear that times when the directions are changing the most are times when intensity is low and changing very little, while times of large intensity change are associated with little directional change. This is consistent with our previous observation that intensity dropped before the large directional changes of the Laschamp Excursion, stayed low during the excursion, and increased again only after the end of the excursion.

[23] Overall, the directional and intensity characteristics of the Laschamp Excursion and related field variability observable before and after the excursion, summarized above, constitute the most complete set of evidence we 

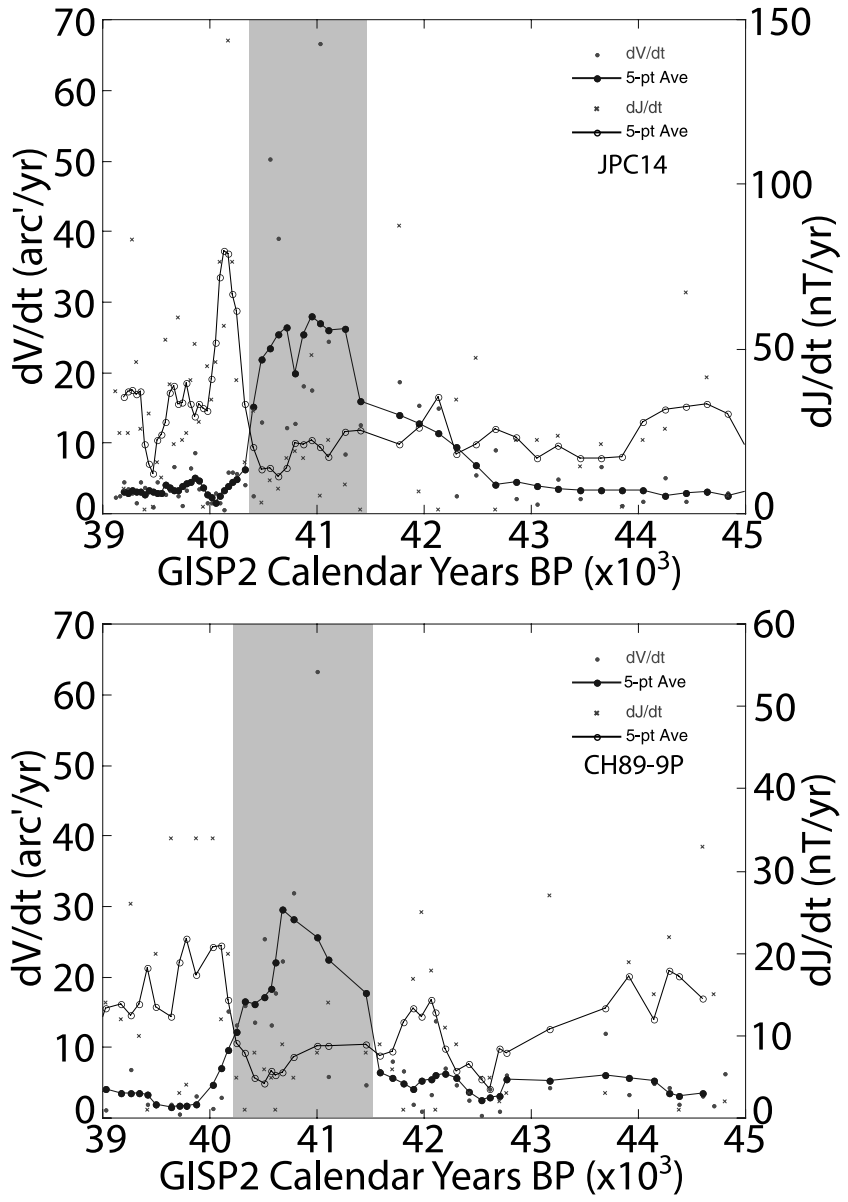

Figure 13. Rates of secular variation surrounding the Laschamp Excursion as estimated from core JPC14 (Blake Outer Ridge) and CH89-9P (Bermuda Rise). The gray regions indicate times of highest directional secular variation rate in both cores. These intervals match times of excursional directions associated with the Laschamp Excursion. Note also that times of highest intensity secular variation rate occur outside (before and after) the gray regions.

have today for excursional field behavior. In the next two sections, we compare the Laschamp Excursion with selected other excursions and normal secular variation and consider whether excursions like the Laschamp Excursion in the western North Atlantic Ocean are more closely related to "normal" secular variation or field reversals.

\section{Comparison Between the Laschamp and Mono Lake Excursions}

[24] The most recent magnetic field excursion for which we have good paleomagnetic evidence is the Mono Lake Excursion [Denham and Cox, 1971; Liddicoat and Coe, 1979], which occurred $\sim 33,000$ cal years B.P. in western North America. The age of the Mono Lake Excursion has recently been contested by Kent et al. [2002], who argue that radiocarbon dates in the Mono Lake basin sediments are anomalously young due to modern carbon contamination. Benson et al. [2003] argue against the analysis of Kent et al. [2002] by using radiocarbon dates from locations outside the Mono Lake Basin to date an ash that lies within the Mono Lake Excursion. Their conclusion is that the Mono Lake Excursion occurs at 31,500-33,500 cal years B.P. That is consistent in age with a paleointensity low observed in many sediment records from around the world $\sim 33,000$ cal years B.P. (Figure 2 ) that we associate with the Mono Lake Excursion.

[25] The pattern of directional and intensity behavior that occurred during the Mono Lake Excursion at Mono Lake, California (type locality, Figure 1) is shown in Figure 15; it is derived from several published records [Denham and Cox, 1971; Liddicoat and Coe, 1979; Lund et al., 1988] and new paleointensity results (M. Schwartz et al., Relative paelointensity for 36,000-12,000 yrs BP from the Wilson Creek Formation, Mono Lake, California, submitted to Earth and Planetary Science Letters, 2004; hereinafter referred to as Schwartz et al., submitted manuscript, 2004). The Mono Lake Excursion contains several characteristics that are remarkably similar to the field behavior described above for the Laschamp Excursion: (1) a distinctive oscillatory variation in inclination and declination with periods close to 1200 years, (2) vector amplitudes, which grow and decay as the field intensity decreases and then increases in a stepwise manner, and (3) near $90^{\circ}$ out-of-phase open loops in field directions and VGPs (Figure 12) with durations on the order of 1200 years. In fact, the Mono Lake Excursion also has a sequence of two clockwise loops followed by a counterclockwise loop, but here the excursional VGPs (Figure 12) occur in both the second (younger) clockwise loop and the subsequent counterclockwise loop. The similarity in both directional and intensity behavior of these two excursions suggests that they were caused by the same general pattern

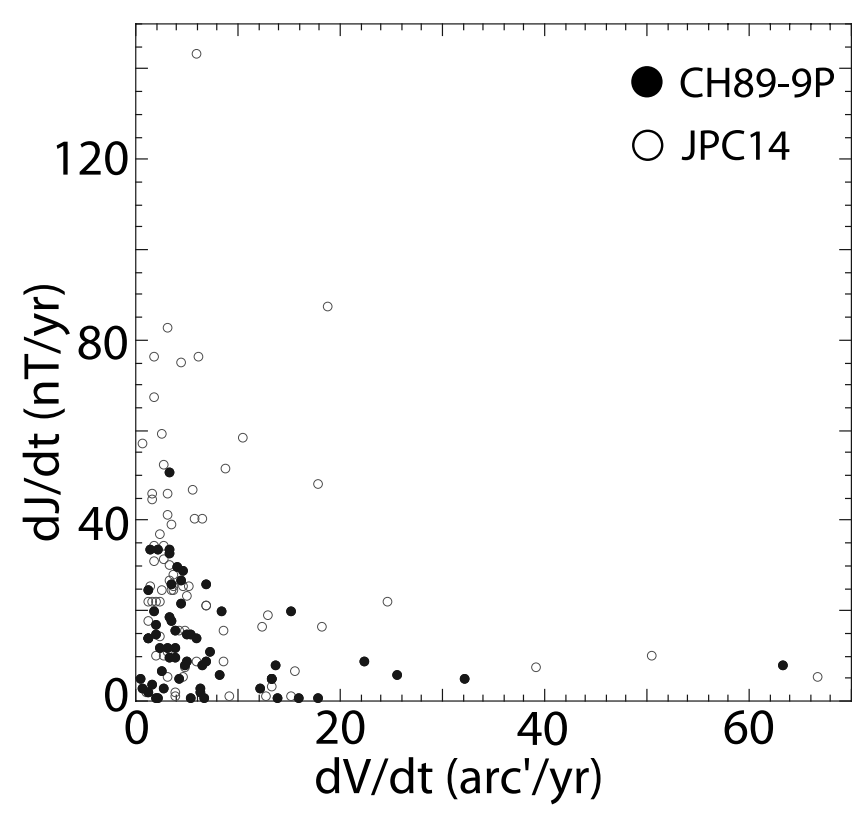

Figure 14. Scatterplot of directional versus intensity secular variation rates for cores JPC14 and CH89-9P. Both cores display a pattern of highest intensity secular variation rate at times of low directional secular variation rate and vice versa. 


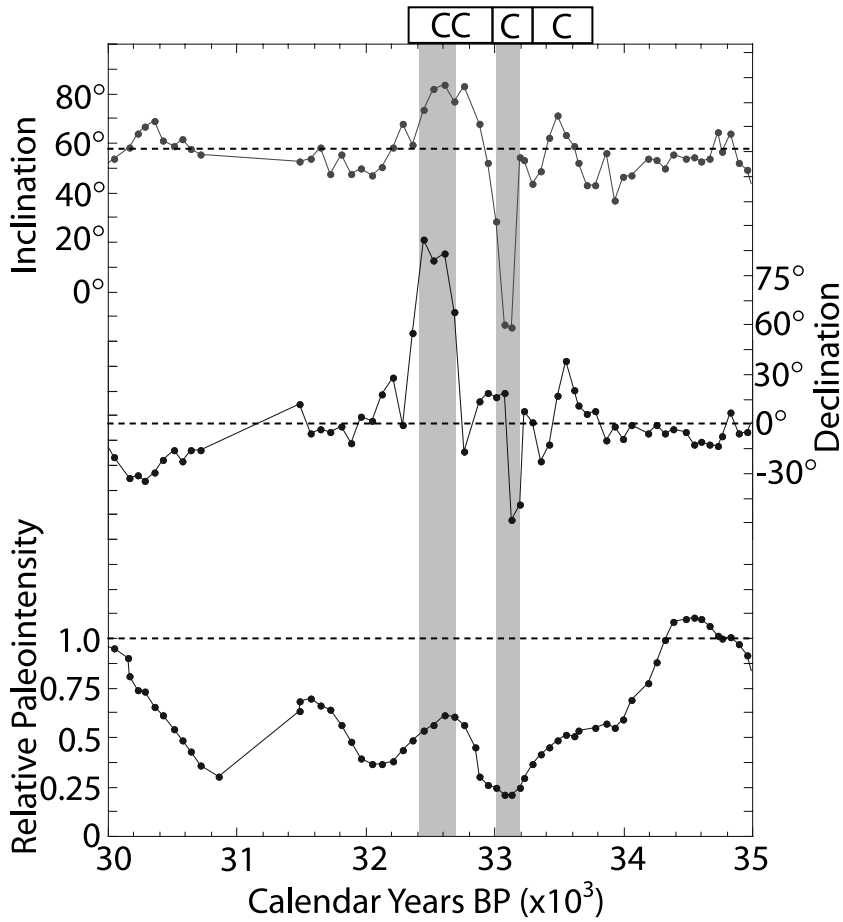

Figure 15. Paleomagnetic secular variation and relative paleointensity records for the Mono Lake Excursion ( 33,000 cal years B.P. [Benson et al., 2003]) as recorded in the lacustrine sediments of Mono Lake, California [Denham and Cox, 1971; Liddicoat and Coe, 1979]. Note the strong similarity in overall style of directional and paleointensity variability to that of the Laschamp Excursion records in Figures 6 and 7. The relative paleointensity record (3-point running average) is derived from $\mathrm{NRM}_{20} /$ SIRM $_{20}$ (Schwartz et al., submitted manuscript, 2004). The gray intervals are times with true excursional directions.

of magnetic flux/fluid flow interaction within the overall core dynamo process.

[26] Selected other, older magnetic field excursions also share much of the same type of variability noted in the Mono Lake and Laschamp Excursions. Examples include the Pringle Falls Excursion [Herrero-Bervera et al., 1989] and its probable equivalent Summer Lake II [Negrini et al., 1994] and Long Valley [Liddicoat and Bailey, 1989] excursions. This observation suggests that there is at least one group of excursions, which we will term class I excursions, that share a distinctive set of directional and intensity variations, all probably due to a particular type of magnetic flux/fluid flow pattern of interaction within the overall dynamo process.

[27] By contrast, we have suggested elsewhere [Henyey et al., 1995] that the Blake Event [Smith and Foster, 1969], a magnetic field excursion that occurred about 125,000 years ago, represents a completely different type (class II) of excursion with very different directional and intensity variations. The key elements of class II excursions appear to be (1) abrupt $\left(\sim 10^{2}\right.$ year) large-scale changes in both inclination and declination together (in phase) followed by (2) static clustering of anomalous directions (and equivalent VGPs) with no significant evidence for large open loops, and (3) an in-phase return to normal inclination and declination values. The Arctic Ocean paleomagnetic records of the Laschamp Excursion, described above, are also examples of class II excursions.

\section{Relationship Between Class I Excursions and Normal Secular Variation}

[28] The similarity of the Laschamp Excursion to other class I excursions does not resolve the fundamental question of whether this group of excursions is more closely related to normal secular variation or to aborted magnetic field reversals. To be sure, the Laschamp Excursion is unlike anything we have seen in the historic record of secular variation, but arguably so is much of paleomagnetic secular variation [Lund, 1989, 1993]. In fact, most of the Laschamp Excursional directional features are quite similar to typical features of paleomagnetic secular variation: 1000-year variations in inclination and declination, near $90^{\circ}$ out-ofphase relationships between inclination and declination, large 1000-year duration open vector loops [Lund, 1993, 1996], and secular variation rates similar to those of the historic field. Also, the spatial scale length associated with the correlation of Laschamp Excursion directions between the western North Atlantic Ocean versus Iceland or France $(\sim 5000 \mathrm{~km})$ is quite similar to spatial scale lengths of correlation noted routinely for Holocene paleomagnetic secular variation records from North America [Lund, 1996].

[29] The only aspect of the Laschamp Excursion and other class I excursions that is not similar to "typical" PSV is the large directional amplitude of the excursions. One might even accommodate that difference in directional amplitude by taking into account that the global-scale magnetic field intensity at the time of the Laschamp Excursion was very low. Under conditions of low globalscale magnetic field intensity, three different conceptual dynamo models of magnetic field secular variation might lead to class I excursions within limited regions.

[30] The first model, popularized by Olson and Hagee [1987] and Hagee and Olson [1989], argues that magnetic field secular variation is caused primarily by dynamo waves propagating near the core-mantle boundary against a backdrop of a global-scale static dipole field. Different regions of the outer core would contain different (independent?) dynamo waves with somewhat different energy levels (intensities). Regional magnetic field excursions could easily occur under conditions where dynamo wave activity in one region would produce relatively large intensity secular variation at a time when the global-scale magnetic field intensity was low. Such a model could permit excursions to be common at times of global magnetic field intensity lows and could also permit different excursions to occur independently in different parts of the Earth at about the same time.

[31] The second and third models are based on the observations of Bloxham and Gubbins [1985] and Gubbins and Bloxham [1987], which identify distinctive magnetic field sources in the outermost core during historic time. One type of source that they identify is core spots, localized regions of relatively high intensity magnetic flux somewhat analogous to sunspots on the Sun [e.g., Stix, 1989]. Core spots tend to occur in oppositely polarized pairs and to 
move about in the outer core [Gubbins and Bloxham, 1987]. Today, core spots are not very strong in intensity and are apparently not a major factor in the observed secular variation at the Earth's surface. However, during times of low global-scale intensity, it is conceivable that a pair of opposite polarity core spots [Gubbins and Bloxham, 1987] of moderate intensity and acting regionally could produce the general style of directional field variability noted in class I excursions. Such models would be phenomenologically akin to radial-dipole models of the Mono Lake Excursion [Liddicoat and Coe, 1979]. Like the dynamo wave model, if core spots can have relatively large intensity at times of low global-scale field intensity, they could commonly produce one or more independent excursions. This model may be less probable inasmuch as core spots do not tend to be important features of secular variation today, but it is not known whether their intensities might have been relatively more important intermittently in the prehistoric past.

[32] The third model argues that a few large-scale convection rolls [Gubbins and Bloxham, 1987; Bloxham and Gubbins, 1989] in the outer core are the primary cause of the Earth's magnetic field. If such convection rolls are allowed to move about regionally on a millennial timescale [Constable et al., 2000] and the magnetic flux regeneration process changes sign in a single convection roll (essentially a local magnetic field reversal), then the regional irregular movement of that single convection roll could produce the observed Laschamp Excursion. It has been previously argued that magnetic field reversals might begin as a local magnetic flux reversal in one region of the outer core [Hoffman, 1979]. However, we might speculate on the basis of the third model and the common appearance of class I excursions that local reversal of magnetic flux regeneration is normal and is not an initial part of the magnetic field reversal process.

[33] In all three conceptual models, the same regional dynamo sources acting at a time of high global-scale field intensity would produce field directions much more similar to what has been documented previously in the Holocene [Lund, 1996]. On the basis of all these comparisons, it seems most reasonable to presume that the Laschamp Excursion in the western North Atlantic Ocean and other class I excursions are a normal part of secular variation related to the intrinsic dynamic character of the magnetic dynamo process between reversals and not necessarily a prelude to magnetic field reversal. The key element in such a hypothesis is that class I excursions are enabled by intervals of very low intensity (less than perhaps $25 \%$ local average values). In this scenario, the observation of anomalously large directional changes is really due to changes in the relative intensities of different regional dynamo sources (in all three models) and not to any fundamental change in the directional patterns of the individual regional dynamo sources. It is this element that makes it easier to imagine class I excursions being more closely related to normal secular variation than aborted reversals. However, the concept of normal secular variation must be based on a much longer (paleomagnetic) record of secular variation than the historic record.

[34] It is important to note that the second and third excursion models (but not the first) could also generate class II excursions under different conditions. However, such models could not generate both class I and class II excursions together. Therefore we believe that the class I Laschamp Excursion behavior in the western North Atlantic Ocean (and Europe) is due to a completely different dynamo source than is the class II Laschamp Excursion behavior in the Arctic Ocean, with the two dynamo sources operating is somewhat different parts of the core.

\section{Conclusions}

[35] We have recovered two new paleomagnetic records of the Laschamp Excursion from deep-sea sediments of the western North Atlantic Ocean (Blake Outer Ridge and Bermuda Rise). These sediments have accumulation rates greater than $20 \mathrm{~cm} / \mathrm{kyr}$ around the time of the excursion, based on carbonate and oxygen isotope stratigraphy. These records provide a high-resolution view of both the paleomagnetic field directional and intensity variation around the time of the Laschamp Excursion that is consistent with the more limited Laschamp Excursion data recovered from European lava flows.

[36] The paleomagnetic records show that the local magnetic field variation during the Laschamp Excursion was characterized by (1) declination changes of $\sim \pm 120^{\circ}$ (almost full reversal), (2) inclination changes of more than $140^{\circ}$ (more than a full reversal) reaching inclinations near $-80^{\circ}$, (3) oscillatory variations ( 1200 year period) in both inclination and declination that grew in amplitude as the local field intensity made a noticeable step decrease and then diminished in amplitude again as the local intensity made a noticeable step increase, (4) near $90^{\circ}$ out-of-phase relationships between inclinations and declinations that produced a distinctive sequence of two open clockwise loops in directions and VGPs followed by a counterclockwise loop, (5) excursional directions and VGPs during both intervals of clockwise looping, (6) local magnetic field intensities less than $10 \%$ of normal that existed for almost 2000 years during the time of excursional field behavior, (7) marked similarity in excursional directions over $\sim 5000 \mathrm{~km}$ spatial scale length, and (8) rates of secular variation $(\mathrm{dV} / \mathrm{dt}$ and $\mathrm{dJ} / \mathrm{dt})$ comparable to historic observations of field behavior but persisting in sign for hundreds of years. All of these directional and intensity features, with the exception of anomalously large directional amplitude, are consistent with what we consider to be normal aspects of magnetic field secular variation.

[37] Comparison of the new Laschamp Excursion paleomagnetic records with records of other late Quaternary excursions (e.g., Mono Lake, Pringle Falls, and Summer Lake II Excursions) suggests that there is a group of excursions, which we term class $\mathrm{I}$, that share a common cause in one particular type of magnetic flux/fluid flow pattern of interaction within the overall core dynamo process. Three general models of secular variation are described that can qualitatively produce the observed directional variations of class I excursions during times of low global-scale magnetic field intensity. On the basis of all these comparisons, we conclude that class I excursions epitomized by the Laschamp Excursion are more closely related to normal secular variation, related to the intrinsic dynamic character of the magnetic dynamo process between 
reversals, and not necessarily a prelude to magnetic field reversal.

\section{References}

Benson, L., J. Liddicoat, J. Smoot, A. Sarna-Wojcicki, R. Negrini, and S. Lund (2003), Age of the Mono Lake excursion and associated tephra, Quat. Sci. Rev., 22, 135-140.

Bleil, U., and G. Gard (1989), Chronology and correlation of Quaternary magnetostratigraphy and nannofossil biostratigraphy in NorwegianGreenland Sea sediments, Geol. Rundsch., 78, 1173-1187.

Bloxham, J., and D. Gubbins (1985), The secular variation of the Earth's magnetic field, Nature, 317, 777-781.

Bloxham, J., and D. Gubbins (1989), The evolution of the Earth's magnetic field, Sci. Am., 261, 68-75.

Bloxham, J., and A. Jackson (1992), Time-dependent mapping of the magnetic field at the core-mantle boundary, J. Geophys. Res., 97, $19,537-19,563$

Bonhommet, N. (1972), Sur la direction d'aimantation des laves de la Chaine des Puys et le comportement de champ en France au cours de l'evenement du Laschamp, these d'Etat, Strasbourg, France.

Bonhommet, N., and J. Babkine (1967), Sur la presence d'aimantations inversees dans la Chaine des Pus, C. R. Acad., Sci., 264, 92-94.

Channell, J., J. Stoner, D. Hodell, and C. Charles (2000), Geomagnetic paleointensity for the last $100 \mathrm{kyr}$ from the sub-Antarctic South Atlantic: A tool for inter-hemispheric correlation, Earth Planet. Sci. Lett., 175, $145-160$.

Chauvin, A., R. A. Duncan, N. Bonhommet, and S. Levi (1989), Paleointensity of the Earth's magnetic field and K-Ar dating of the Louchadiere volcanic flow (central France): New evidence for the Laschamp Excursion, Geophys. Res. Lett., 16, 1189-1192.

Constable, C., C. L. Johnson, and S. P. Lund (2000), Global geomagnetic field models for $0-3 \mathrm{ka}$ : transient or permanent flux lobes, Philos. Trans. R. Soc. London, Ser. A, 358, 991-1008.

Denham, C. E., and A. Cox (1971), Evidence that the Laschamp polarity event did not occur 13,300-30,400 years ago, Earth Planet. Sci. Lett., $13,181-190$

Gubbins, D., and J. Bloxham (1987), Morphology of the geomagnetic field and implications for the geodynamo, Nature, 325, 509-511.

Hagee, V. L., and P. Olson (1989), An analysis of paleomagnetic secular variation in the Holocene, Phys. Earth Planet. Inter., 56, 266-284.

Haskell, B. J. (1991), The influence of deep western North Atlantic circulation on the late Quaternary sedimentation of the Blake Outer Ridge, Ph.D. dissertation, Duke Univ., Durham, N. C.

Haskell, B. J., T. C. Johnson, and W. J. Showers (1991), Fluctuations in deep western North Atlantic circulation on the Blake Outer Ridge during the last deglaciation, Paleoceanography, 6, 291-312.

Henyey, S., S. Lund, M. Schwartz, and L. Keigwin (1995), Paleomagnetic secular variation during oxygen isotope stages $5-6$ : Further evidence for the relationship between excursions and normal secular variation, Eos Trans. $A G U, 76(46)$, Fall Meet. Suppl., F165.

Herrero-Bervera, E., C. E. Helsley, S. Hammond, and L. Chitwood (1989), A possible lacustrine paleomagnetic record of the Blake episode from Pringle Falls, Oregon, USA, Phys. Earth Planet. Inter., 56, 112-123.

Hirooka, K., C. Tobita, T. Yokohama, and S. Nakaya (1977), On the excursion of the latest Pleistocene recorded in Ontake tephra, Ina, central Japan, Rock Magn. Paleogeophys., 4, 81-87.

Hoffman, K. (1979), Behavior of the geodynamo during reversal: A phenomenological model, Earth Planet. Sci. Lett., 44, 7-15.

Keigwin, L., and G. A. Jones (1994), Western North Atlantic evidence for millennial-scale changes in ocean circulation and climate, J. Geophys. Res., 99, 12,397-12,410.

Kent, D., S. Hemming, and B. Turrin (2002), Laschamp Excursion at Mono Lake?, Earth Planet. Sci. Lett., 197, 151-164.

King, J. W., and J. E. T. Channell (1991), Sediment magnetism, environmental magnetism, and magnetostratigraphy, U.S. Natl. Rep. Int. Union Geod. Geophys. 1987-1990, Rev. Geophys., 29, 358-370.

Kissel, C., C. Laj, L. Labeyrie, T. Dokken, A. Voelker, and D. Blamant (1999), Rapid climatic variations during marine isotope stage 3: Magnetic analysis of sediments from Nordic seas and North Atlantic, Earth Planet. Sci. Lett., 171, 489-502.

Kristjansson, L., and A. Gudmundsson (1980), Geomagnetic excursion in late-glacial basalt outcrops in southwestern Iceland, Geophys. Res. Lett., 7, 337-340.

Kulikova, L., and G. Pospelova (1979), A short-period geomagnetic field inversion 40 thousand years ago, Izv. Earth Phys., 15, 415-422.

Laj, C., C. Kissel, A. Mazaud, J. Channell, and J. Beer (2000), North Atlantic paleointensity stack since $75 \mathrm{ka}$ (NAPIS-75) and the duration of the Laschamp Event, Philos. Trans. R. Soc. London, Ser. A, 358, $1009-1025$.
Levi, S., and R. Karlin (1989), A sixty thousand year paleomagnetic record from Gulf of California sediments: Secular variation, late Quaternary excursions, and geomagnetic implications, Earth Planet. Sci. Lett., 92, 219-233.

Levi, S., H. Audunsson, R. A. Duncan, L. Kristjansson, P.-Y. Gillot, and S. Jakobsson (1990), Late Pleistocene geomagnetic excursion in Icelandic lavas: Confirmation of the Laschamp Excursion, Earth Planet. Sci. Lett., 96, 443-457.

Liddicoat, J., and R. Bailey (1989), Short reversal of the paleomagnetic field about 280,000 years ago at Long Valley, California, in Geomagnetism and Paleomagnetism, edited by F. Lowes et al., pp. 137-153, Springer, New York.

Liddicoat, J., and R. Coe (1979), Mono Lake geomagnetic excursion, J. Geophys. Res., 84, 261-271.

Lund, S. (1989), Paleomagnetic secular variation, in Encyclopedia of Solid Earth Geophysics, edited by D. E. James, pp. 876-888, Springer, New York.

Lund, S. P. (1993), Paleomagnetic secular variation, in Trends in Geophysical Research, pp. 143-155, Counc. of Sci. Res. Integration, Trivandrum, India.

Lund, S. (1996), A comparison of Holocene paleomagnetic secular variation records from North America, J. Geophys. Res., 101, 8007-8024.

Lund, S. P., and S. K. Banerjee (1985), Late Quaternary paleomagnetic field secular variation from two Minnesota lakes, J. Geophys. Res., 90, 803825 .

Lund, S. P., and L. Keigwin (1994), Measurement of the degree of smoothing in sediment paleomagnetic secular variation records: An example from late Quaternary deep-sea sediments of the Bermuda Rise, western North Atlantic Ocean, Earth Planet. Sci. Lett., 122, 317-330.

Lund, S. P., J. C. Liddicoat, K. L. Lajoie, T. L. Henyey, and S. W. Robinson (1988), Paleomagnetic evidence for long-term $\left(10^{4}\right.$ year) memory and periodic behavior in the Earth's core dynamo process, Geophys. Res. Lett. , 15, 1101-1104.

Lund, S. P., B. Haskell, and T. C. Johnson (1989), Paleomagnetic secular variation records for the last 100,000 years from deep sea sediments of the northwest Atlantic Ocean, Eos Trans. $A G U, 70,1073$.

Lund, S., G. Acton, B. Clement, M. Okada, and T. Williams (2001), Paleomagnetic records of stage 3 excursions from ODP Leg 172, Proc. Ocean Drill. Proj. Sci. Results [CD-ROM], 172.

Meynadier, L., J.-P. Valet, R. Weeks, N. Shackleton, and V. L. Hagee (1992), Relative paleointensity of the field during the last $140 \mathrm{ka}$, Earth Planet. Sci. Lett., 114, 39-57.

Negrini, R., D. Erbes, A. Roberts, K. Verosub, A. Sarna-Wojcicki, and C. Meyer (1994), Repeating waveform initiated by a $180-190 \mathrm{ka}$ geomagnetic excursion in western North America: Implications for field behavior during polarity transitions and subsequent secular variation, J. Geophys. Res., 99, 24,105-24,119.

Nowaczyk, N., and M. Antonow (1997), High-resolution magnetostratigraphy of four sediment cores from the Greenland Sea: I. Identification of the Mono Lake excursion, Laschamp and Biwa I/Jamaica geomagnetic polarity events, Geophys. J. Int., 131, 310-324.

Nowaczyk, N., and M. Baumann (1992), Combined high-resolution magnetostratigraphy and nannofossil biostratigraphy for late Quaternary Arctic Ocean sediments, Deep Sea Res., 39, 567-701.

Nowaczyk, N., and J. Knies (2000), Magnetostratigraphic results from the eastern Arctic Ocean: AMS ${ }^{14} \mathrm{C}$ ages and relative paleointensity data of the Mono Lake and Laschamp geomagnetic reversal excursions, Geophys. J., Int., 140, 185-197.

Nowaczyk, N., T. Frederichs, A. Eisenhauer, and G. Gard (1994), Magnetostratigraphic data from late Quaternary sediments from the Yermak Plateau, Arctic Ocean: Evidence for four geomagnetic polarity events within the last $170 \mathrm{ka}$ of the Brunhes Chron, Geophys. J. Int., 117, $453-471$

Olson, P., and V. L. Hagee (1987), Dynamo waves and paleomagnetic secular variation, Geophys. J. R. Astron. Soc., 88, 139-159.

Peddie, N., and A. Zunde (1988), The magnetic field of the Earth: 1985, U.S. Geol. Surv. Geophys. Invest. Map, GP-987-1.

Roperch, P., N. Bonhommet, and S. Levi (1988), Paleointensity of the Earth's magnetic field during the Laschamp Excursion and its geomagnetic implications, Earth Planet. Sci. Lett., 88, 209-219.

Schwartz, M. (1997), Paleointensity of the Earth's magnetic field over the last 200 ky, Ph.D. dissertation, Univ. of South. Calif., Los Angeles.

Schwartz, M., S. P. Lund, and T. C. Johnson (1996), Environmental factors as complicating influences in the recovery of quantitative geomagneticfield paleointensity estimates from sediments, Geophys. Res. Lett., 23, 2693-2696.

Schwartz, M., S. P. Lund, and T. C. Johnson (1998), Geomagnetic field intensity from $12,000-71,000$ years $\mathrm{BP}$ as recorded in deep sea sediments of the Blake Outer Ridge, North Atlantic Ocean, J. Geophys. Res., $103,30,407-30,416$. 
Smith, J. D., and J. Foster (1969), Geomagnetic reversal in Brunhes normal polarity epoch, Science, $163,565-567$.

Stix, M. (1989), The Sun, an Introduction, 390 pp., Springer, New York. Stoner, J., J. Channell, J. Hillaire-Marcel, and C. Kissel (2000), Geomagnetic paleointensity and environmental record from Labrador Sea core MD95-2024: Global marine sediment and ice core stratigraphy for the last 100 kyr, Earth Planet. Sci. Lett., 183, 161-177.

Stoner, J., C. Laj, J. Channell, and C. Kissel (2002), South Atlantic (SAPIS) and North Atlantic (NAPIS) geomagnetic paleointensity stacks $(0-80 \mathrm{ka})$ Implications for inter-hemispheric correlation, Quat. Sci. Rev., 21, 11411151.

Stott, L. C. Poulsen, S. Lund, and R. Thunell (2002), Super ENSO and global climate oscillations at millennial time scales, Science, 297, 222226.

Thouveny, N., K. Creer, and D. Williamson (1993), Geomagnetic moment variations in the last 70,000 years, impact on production of cosmogenic isotopes, Global Planet. Change, 7, 157-172.
Tric, E., J.-P. Valet, P. Tucholka, M. Paterne, L. Labeyrie, F. Guichard, L. Tauxe, and M. Fontugne (1992), Paleointensity of the geomagnetic field during the last 80,000 years, J. Geophys. Res., 97, 9337-9351. Yamazaki, T., and N. Ioka (1994), Long-term secular variation of the geomagnetic field during the last $200 \mathrm{kyr}$ recorded in sediment cores from the western equatorial Pacific, Earth Planet. Sci. Lett., 128, $527-544$

T. Johnson, Large Lakes Observatory, University of Minnesota at Duluth, 10 University Drive, Duluth, MN 55812, USA.

L. Keigwin, Woods Hole Oceanographic Institution, McLean Lab MS 8360, 360 Woods Hole Road, Woods Hole, MA 02543-1539, USA.

S. P. Lund and M. Schwartz, Department of Earth Sciences, University of Southern California, University Park, Los Angeles, CA 90089-0740, USA. (slund@usc.edu) 